\title{
Per Student Expenditure and Learning Output in Science and Mathematics Subjects in Public Secondary Schools in Siaya County, Kenya
}

\author{
Lucy Akinyi Eunice ${ }^{1}$ Prof. John Aluko Orodho*2 Dr. Thaddaeus Ogola Rugar ${ }^{3}$ \\ 1. Doctorate Student in the Department of Educational Management, Policy and Curriculum Studies, School of \\ Education, Kenyatta University, Kenya. \\ E-mail: lusiakinyi@gmail.com \\ 2. *The corresponding author is an Associate Professor Specialized in Curriculum Studies, Educational Research \\ and Statistics, Department of Educational Management, Policy and Curriculum Studies, School of Education, \\ Kenyatta University, Kenya. \\ E-mail: Orodhojohn@gmail.com. \\ 3. A Lecturer Specialized in Planning and Economics of Education, Department of Educational Management, \\ Policy and Curriculum Studies, School of Education, Kenyatta University, Kenya
}

\begin{abstract}
The Government of the Republic of Kenya has continued to increase expenditure to education to enable acquisition of learning resources. However, low learning outputs have continued to be realized every time secondary education summative evaluation results are released. The purpose of this study was to establish the influence of per student expenditure on learning output in science and mathematics in public secondary schools in Siaya County, Kenya. The study was underpinned on the Education Production Functions Model by Hanushek (2008). The study employed convergent parallel mixed methods design. The target population for this study was 6175 comprising 247 principals, 988 teachers and 4940 students from the 247 public secondary schools in the study locale. A stratified random sampling technique was employed to select 376 respondents was used from 15 sampled schools. The average termly class mean scores were used to measure the students' learning output in the schools. Questionnaires, interview guides and document analysis guide used to collect data on per student expenditure and learning output. Test re-test method was used to determine reliability of the instruments. The quantitative data was analyzed using descriptive and inferential statistics and presented in tables and graphical format, while the qualitative data was analyzed thematically and presented in quoted texts. The study found a positive linear relationship between per student expenditure and learning output. The coefficient of determination $\mathrm{R}^{2}$ was established at $61.9 \%$. In conclusion, schools which had appropriate resource inputs to meet quality learning requirements also had better learning output. Though nearly all the study schools fall short of the policy standard requirements with the predictor variable, the more the resources, the better the learning output in the schools. The study recommended that the national government should increase grant to cater for more school expenditure
\end{abstract}

Keywords: Per Student Expenditure, Educational Expenditure, Learning Output, Secondary Schools, , Kenya. DOI: $10.7176 /$ RHSS/12-4-05

Publication date: February $28^{\text {th }} 2022$

\section{INTRODUCTION}

\section{Background information}

The government has continuously increased its expenditure towards education; thus, catering for costs that were initially left for parents and guardians to shoulder. These include: paying for tuition fees, examination fees and buying text books. The government has also availed the National Government Constituency Development Fund (NG-CDF) for financial cushioning on students' charges (Thuo, 2020; Ngalu \& Bommet, 2014). This is to enable the government to meet its policy on Education for All (EFA), global goal on universal secondary school completion by the year 2030 and build on knowledge, skills and values to enable increased productivity that will help root the country into her newly acquired status as a middle income country (UNESCO, 2015b, 2014). Despite these government initiatives to enable quality education, poor learning output is overarching the education sector with half of the candidates attaining low grades in the national examination. This poses a major concern to the education stakeholders who have to find lasting solutions to the persistently low learning output which threaten students' global competitiveness.

It is instructive to note that a large body of literature reviewed concur that quality education is determined by the effectiveness of learning, the extent to which their education translates into a range of personal, social and developmental advantages. The quality imparted vary per school depending on the internal school characteristics, such as, relevant aims, good use of time and available support materials which are deployed equitably and effectively within a school environment that is supportive to learning (UNESCO, 2015a). UNESCO (2019c) 
further emphasizes that the appropriate skill acquisition is embodied in the provision of the required resources for quality teaching and learning to take place. Many governments therefore have embarked on increasing expenditure towards education so as to cater for the required resources for quality learning. A study by UNICEF (2017), details that it is the mandate of the governments to ensure the right of access to education; that education for all is not a mirage and secondary education be available and accessible to everyone. Moreover, it should avail generous incentives to poor adolescents and youth to continue their education. UNESCO (2019b) invokes the new global education goal SDG-4 including the pledge that all girls and boys complete free, equitable and quality primary as well as secondary education leading to relevant and effective outcomes.

This leads to questioning of the credibility of anticipating for quality education, $100 \%$ completion and eradication of poverty from the face of the earth. This is because households who take their children to the public schools; more than half of them can barely afford a meal a day and live below dollars 1.22 a day (UNESCO, 2014, 2015b). OECD (2018) reveals that per student expenditure to education institutions is weighted against the country's gross domestic product (GDP) Per Capita. Are households realizing financial inadequacies in meeting their cost obligations for quality education provisions? Quality education is realized when appropriate learning materials and infrastructure is put in place (UNESCO, 2018a). This study examined per student expenditure in various schools based on the value of the schools (public expenditure and private expenditure versus enrolment) and established their influence on learning output.

\subsection{The State of the Art Review}

Per student expenditure refers to funding from the government, private (households) and other sources for a given level of education per year and in this case it was secondary education in this study. UNESCO (2021) indicates that finance for education mainly comes from public funds from government sources and private contributions from households. Other sources such as donor funding may not be very adequate, reliable and sustainable. On its $5^{\text {th }}$ brief on priority equitable and sustainable education, UNESCO (2021) indicate mixed results about the causal relationship between school funding and performance. Governments have enumerated vote heads that are financed for quality education provisions in schools yielding to public account, this include; teacher remuneration and key facilities, and private account for cost sharing in education (UNESCO, 2012). The public and private expenditure to education constitute the per student expenditure; an indicator which reflects the amount of resources invested on average in a single student. The public and private expenditure to education are hereby discussed on their influence on students learning output.

A survey study by Lucas and Mbiti (2014) on school quality and its effects on student's achievement in Kenya, indicate that schools of high repute in terms of performance had no value added on the leaners rather the sterling reputation reflect the selection of students' and not the school's ability to generate value added test scores. The study recommended that the elite schools could focus resources and target instruction for improved performance. However, Lucas and Mbiti (2014) study did not assess the influence of school expenditure on students' scores which this study explored.

\subsection{The Purpose of the Study}

This study sought to determine the influence of per student expenditure on learning output in science and mathematics subjects in Public Secondary Schools in Siaya County, Kenya.

\subsection{Theoretical Framework}

The study was based on Education Production Functions Model by Hanushek (2008). The Education Production Functions Model embraces the underlying principle in the theory of Production, which states that the quantity of output that a firm can produce is a function of the quantity of inputs to production which a firm employs. The production function is expressed in a linear form as; $Q=f\left(X_{1}, X_{2} \ldots . . X_{n} ; K_{1}, K_{2} \ldots . . K_{m}\right)$ where $Q$ denotes the quantity of a firm's output, $\mathrm{X}_{1}, \mathrm{X}_{2}$ and $\mathrm{X}_{\mathrm{n}}$ are the presumed variable factor inputs while $\mathrm{K}_{1}, \mathrm{~K}_{2} \ldots . . \mathrm{K}_{\mathrm{m}}$ denote the fixed factors employed in the production of Q (Solow, 1966, KIPPRA, 2017). When adopting the theory of production to an education context, the inputs are converted to produce a range of outputs through the teaching and learning process as exploited in this study through the realms of the Education Production Functions Model by Hanushek (2008). The education production function model was relevant to this study because; the concept helped in the evaluation of key quality input areas to education and assessed their contribution to learning output, through regression models.

\section{RESEARCH METHODOLOGY}

The study employed mixed methods research design by specifically using convergent parallel design in a four step multiphase whereby; in the first phase of the research process, quantitative and qualitative data were collected independently though concurrently. Second, quantitative and qualitative data were analysed concurrently but separately. Third, the quantitative and qualitative results were merged while discussing the 
areas of convergence, divergence and complementarity. In the final phase, the quantitative and qualitative results were interpreted to help answer the research questions by deducing the general picture of the results per objective area (Orodho, Nzabalirwa, Odundo, Waweru \& Ndayambaje,2016) . This design was appropriate to this study because it enabled the generation of quantitative and qualitative information about a similar concept; the status of the school quality variables. It also allowed for in-depth views and explanations from the participants on the same concept (Creswell, 2014; Orodho,2017).

The study target population comprised of 6,175 school principals, science and mathematics teachers and students (class secretaries and subject representatives) from all the public secondary schools in Siaya County, Kenya. From the target population of 6,175, there were 247 principals, 988 teachers and 4,940 students. The Science (Chemistry, Biology and Physics) and Mathematics teachers were targeted because they are the direct facilitators of learning in the subjects; thus, one teacher per subject area (head of subject) hence four teachers for the four subjects (Chemistry, Biology Physics and Mathematics) per school totalling to 988 teachers across the 247 schools. Science and Mathematics teachers were targeted because the subjects have consistently recorded the lowest achievement mean index in the national examination in the county. The students' class secretaries and subject representatives from form one to four, were targeted because they are tasked with the responsibility of representing their classes effectively in any issues.

The study employed stratified and simple random sampling. The sampling units were schools drawn categorically from; sub- county, county, extra county and national schools. These schools were either mixed day schools, boarding girls' schools, boarding boys' schools or mixed day and boarding type. Slovene (1960) formula to determine the sample size as sample size of 376 participants.

Three types of instruments were used in this study. They include document analysis guide for the principals, questionnaires for the school principals, questionnaires for teachers and students, and interview schedules for principals, teachers and students on school quality variables and learning output. The use of multiple instruments on each type of respondent is in conformity with the requirements of the mixed methods design to enable the generation of both quantitative and qualitative data for corroboration and complementarity purposes. Piloting was conducted in public secondary schools in Siaya County to help determine validity and reliability of the instruments thus help identify any ambiguities in the research questions from the instruments. $1 \%$ percent of study units and respondents in each category was used. Quantitative data analysis was conducted with the assistance of Statistical Package for Social Sciences (SPSS), while qualitative data was analysed thematically (Orodho, Ampofo, Bizimana, \& Ndayambaje, 2016).

\section{RESEARCH FINDINGS AND DISCUSSION}

\section{Per Student Expenditure and Learning Output}

Data on per student expenditure was arrived at cumulatively from public and private expenditure areas which were supplied by the study participants through the use of document analysis guides (fee structures and financial statements) and questionnaires. The respondents were asked to supply the information regarding the amount of money charged by the school in different category areas namely; Parents Association (PA) charges for remedial charges, salary for teachers under BOM terms, development fees, and also the cost of learning facilities which include; classrooms, laboratories, laboratory equipment, land, uniform costs, among others. These cost areas were categorised under public and private expenditure areas. The total expenditure per school was then divided by school enrolment to yield the per student expenditure for each school. The data on per student expenditure was subjected to descriptive and regression analysis. Data on per student expenditure was analysed and results presented in Table 3,4,5,6,7,8,9 and 10 .

\section{School Expenditure Areas}

These are areas where schools incurred costs as they spent money to acquire the resources needed in the learning process per year. The learning resources were significant to this study because they can influence students' scores in the schools. Table 3 gives the average expenditure across different categories of schools. The principals were asked to supply information regarding the cost of; staff, buildings, land, laboratory equipment, laboratory chemicals, government capitation, fee payable per child grant, academic support programme levy per child, development fee, cost of school uniform, transport expenses per child and meals levy per child. 
Table 3: Average Expenditure across Different Categories of Schools per Year, in Kenya Shilling

\begin{tabular}{|c|c|c|c|c|}
\hline $\begin{array}{l}\text { Category of } \\
\text { School Entry }\end{array}$ & National & Extra County & County & Sub County \\
\hline$N$ & 2 & 3 & 4 & 6 \\
\hline \multicolumn{5}{|l|}{ Public expenditure } \\
\hline Cost of buildings & 534000000 & 260000000 & 64680000 & 40400000 \\
\hline Cost of land & 81400000 & 56000000 & 34000000 & 14000000 \\
\hline Cost of Laboratories & 30000000 & 12000000 & 4000000 & 600000 \\
\hline Cost of staff & 72000000 & 44000000 & 8720000 & 3600000 \\
\hline Capitation grant & 76000000 & 33000000 & 11120000 & 6672000 \\
\hline Laboratory equipment & 74000000 & 39000000 & 16000000 & 4000000 \\
\hline Cost of lab chemicals & 5000000 & 2000000 & 700000 & 300000 \\
\hline Total Public Expenditure & 872400000 & 446000000 & 131540000 & 69872000 \\
\hline Average Public expenditure & 446926 & 348437.50 & 252961.54 & 134369.23 \\
\hline \multicolumn{5}{|l|}{ Private Expenditure } \\
\hline Total cost of uniform & 15000 & 11000 & 7500 & 4000 \\
\hline Development fee & 10000 & 7000 & 4000 & 2000 \\
\hline Academic support program levy & 10000 & 6000 & 4000 & 1000 \\
\hline School fees & 53544 & 45000 & 40000 & 12000 \\
\hline Transport cost & 10500 & 7500 & 4500 & 1000 \\
\hline Cost of writing materials & 7000 & 5540 & 3500 & 2000 \\
\hline Average Private Expenditure & 106044 & 82040 & 63500 & 22000 \\
\hline Per Student Expenditure & 453249.87 & 306,471 & $\mathbf{1 5 0 , 0 0 7 . 8 0}$ & $112,500.00$ \\
\hline
\end{tabular}

$N=376$

Source: Principals' questionnaire Teachers Questionnaires and students' questionnaires

Table 3 shows the average expenditure for the four categories of schools namely; national, extra county, County and Sub- County in Kenya shillings (Kshs). The national schools had the highest per student expenditure at an average of Kshs 453 249.87, followed by the extra county schools at Kshs 306,471, county schools at Kshs $150,007.80$ and lastly the sub county at Kshs 112,500 . Per student expenditure in sub county schools was nearly quarter $(25 \%)$ of that of the national schools, a third (30\%) of Extra County schools per student expenditure and almost half $(50 \%)$ of the County schools per student expenditure.

The expenditure on buildings in extra county schools was $50 \%$ of the expenditure on buildings in the national schools. The expenditure on buildings in county and sub county schools was $10.8 \%$ and $7 \%$ respectively of the expenditure on buildings of the national schools.

The average expenditure on each item varied greatly as conspicuously noticeable by category of schools. The expenditure on laboratories was higher in the national school category followed by extra county schools then county schools and finally sub- county schools. It was established that each science subject (physics, chemistry and biology) had an independent laboratory specific for that subject thus; there were chemistry laboratory, physics laboratory and biology laboratory in the two national schools. Furthermore, in the national schools, each subject had more than one laboratory; in one national school, chemistry had four laboratories, biology three laboratories and physics two laboratories. This means that every class could have a laboratory lesson across different subjects running at the same time, which increases the laboratory hours in all the science subjects in the schools. In the county and sub county schools, each school generally had one laboratory shared across the three science subjects. This means that only one science lesson could be conducted in the laboratory at any given time as the rest of the science lessons were taught theoretically, thus reducing the laboratory hours each subject could have in the laboratory.

The expenditure on laboratory equipment was equally higher in national schools and reduced steadily to sub county schools. This implies that sub county schools spend less in laboratory resource requirements which means students' frequency of interaction with the laboratory equipment is reduced. Laboratory chemical expenditure by school category displayed that sub county schools spent the least amount of money on laboratory chemicals, followed by county schools while the national schools spent the highest amount of money on laboratory chemicals. The sub county schools in essence spent only $6 \%$ of the amount that the national schools spend on chemicals, $15 \%$ of extra county schools spending and $42 \%$ of the county schools spending on chemicals. This trend implies that the frequency of exposure to the laboratory practical in the subjects is less in sub county schools, and increases in the higher school categories.

The expenditure areas in the private expenditure category included; cost of uniform, development fee, academic support programme levy, school fees and cost of writing materials. These costs were cheaper at the sub county school levels and rose with every higher category of school. The costs were five times cheaper at the sub 
county schools than at the national schools, thus the sub county schools' private expenditure were $20 \%$ of the national schools' private expenditure.

Majority $(80.06 \%)$ of the students indicated that they pay remedial fee of between Kshs 1000 to 1500 per term while about $20 \%$ indicated that they pay remedial fee of Kshs 2000 per term. $70 \%$ of the student respondents indicated that they incurred between Kshs 1500 to 2000 per term in transport while $40 \%$ spent more than Kshs 2500 per term in transport. $19.9 \%$ of the student respondents indicated that they pay for laboratory chemicals at about Kshs 1000 per term. Majority of the students indicated that they spend between Kshs 1000 to 2000 per term on writing materials stationary.

The sub county schools are not associated with higher per student expenditure on school fees because they are purely mixed day schools; therefore, they do not pay the boarding fee, nonetheless, they pay majorly the lunch fee which was captured as school fees in the fee statement. This significantly reduced the private expenditure in the sub county schools.

The public expenditure comprised of expenditure on staff, expenditure on land, expenditure on buildings and capitation education grant to facilitate school operations. The cost of staff in sub county schools was $7.5 \%$ of the cost of staff in the national schools and $41.6 \%$ of the cost of staff in the extra county schools. The total capitation grant received by schools also increased with higher categorization of schools. The national schools received $1139.09 \%$ of the national government capitation grant above what the sub county schools received. The extra county schools received almost half (43.4\%) of the amount of the capitation grant received by the national schools. This trend was replicated with every subsequent category of schools; the sub county schools receiving the lowest capitation grant.

The per student capitation grant was constant at Ksh 22,244 across category of schools. However, the national school received the largest amount due to the large student population in the schools. The subsequent categories of schools; extra county, county to the least ranking category; sub county schools, depict a trend of systematic reduction in the expenditure, with significantly large deviations/gaps from each school category. This results show that there is significant variations in per student expenditure across the four categories of schools.

\section{Principals Opinion on Timeliness of Fee Payment}

The school expenditure is settled through fee payment besides the government capitation grant. The school principals were asked to supply their opinion regarding the timeliness of fee payment in their schools. The information provided is presented in Table 4.6.

Table 4: Principals Opinion on Timeliness of Fees Payment

\begin{tabular}{llc}
\hline Responses & Frequency & Percent \\
\hline All students pay in time & $\mathbf{0}$ & $\mathbf{0}$ \\
Averagely pay in time & $\mathbf{1}$ & $\mathbf{6 . 6 7}$ \\
Majority delay a bit with payment & $\mathbf{8}$ & $\mathbf{5 3 . 3 3}$ \\
All students do not pay in time & $\mathbf{6}$ & $\mathbf{4 0 . 0 0}$ \\
Some students do not pay at all & $\mathbf{4}$ & $\mathbf{2 7 . 0 0}$ \\
\hline
\end{tabular}

\section{$N=15$}

\section{Source: Principals Questionnaire}

Table 4 shows that majority (53.33\%) of the principals indicated delay in fee payment while nearly half $(40 \%)$ of the students do no pay fees in time while about $27 \%$ of the students do not pay at all. This trend could have an influence on learners' scores.

\section{Principals Proposals Regarding School Expenditure for Effective Learning}

Principals were asked to propose measures that can be taken to ensure effective provision of learning requirement in their schools. The responses are presented in Table 4.7.

Table 5: Principals Proposals on measures that should be put in place regarding school expenditure that may influence learning

\begin{tabular}{lll}
\hline Responses & Frequency & Percent \\
\hline Government to increase per capita grant & $\mathbf{9}$ & $\mathbf{6 0}$ \\
Timely disbursement of capitation grant & $\mathbf{1 0}$ & $\mathbf{6 6 . 6 7}$ \\
parents to pay fees in time & $\mathbf{5}$ & $\mathbf{3 3 . 3 3}$ \\
Subsidy on student meals & $\mathbf{1 0}$ & $\mathbf{6 6 . 6 7}$ \\
Increase CDF allocation & $\mathbf{8}$ & $\mathbf{5 3 . 3 3}$ \\
Increase infrastructure grant & $\mathbf{8}$ & $\mathbf{5 3 . 3 3}$ \\
\hline
\end{tabular}

\section{Source: Principals Questionnaire}

Table 5 shows that most principals $(66.67 \%)$ felt that timely disbursement of capitation grant and subsidy on students' meals could influence learning in schools. 
This was followed by $60 \%$ of principals who indicated that the government should increase per capita grant. About half of the principals $(53.33 \%)$ indicated increase in CDF allocation and also that the government should increase infrastructure grant.

Per Student Expenditure and Learning Output in Schools

Per student expenditure and students learning output in the study schools was generated, tabulated and presented in Table 6.

Table 6: Per Student Expenditure and Learning Output in Schools

\begin{tabular}{|l|l|l|}
\hline S/N & Per student expenditure & Learning output \\
\hline 1 & $482,558.00$ & 8.11 \\
\hline 2 & $423,941.74$ & 6.23 \\
\hline 3 & $357,583.00$ & 5.06 \\
\hline 4 & $331,326.00$ & 4.33 \\
\hline 5 & $296,621.00$ & 4.19 \\
\hline 6 & $243,451.00$ & 4.11 \\
\hline 7 & $179,396.00$ & 4.03 \\
\hline 8 & $149,132.05$ & 3.26 \\
\hline 9 & $129,282.00$ & 3.23 \\
\hline 10 & $114,500.00$ & 3.12 \\
\hline 11 & $112,500.00$ & 3.09 \\
\hline 12 & $112,350.00$ & 3.07 \\
\hline 13 & $112,300.00$ & 2.96 \\
\hline 14 & $110,300.00$ & 2.76 \\
\hline 15 & $110,250.00$ & 2.43 \\
\hline Average & $\mathbf{2 0 9 , 5 8 3 . 1 4}$ & $\mathbf{3 . 9 9}$ \\
\hline$N=376$ & & \\
\hline
\end{tabular}

\section{$N=376$}

Source: Principals questionnaire, Teachers questionnaire and students' questionnaire

Table 6 shows that as the per student expenditure increases, the students learning output also increases. This implies that schools with higher per student expenditure performed better than the schools with low per student expenditure. This is factual because, schools with low per student expenditure also have fewer infrastructural and instructional resources in the schools thus may lack the necessary learning requirements and this hinder learning, the schools with higher per student expenditure have more infrastructural and instructional resources which are used in the learning process and would enhance learning output. This depicts the input output relationship as described by the education production functions model (Hanushek, 2008).

\section{a) Students Learning Output}

Table 2 presents students learning output/ mean scores by school category. The respondents were asked to supply information on the subject mean scores in mathematics and science subjects (Chemistry, Biology and Physics). The subject teachers supplied the information regarding the subject mean scores across various classes (form 1, form 2, form 3 and form 4 ) by availing the mark sheets and also through filled in questionnaires. This variable was significant because it enabled the determination of the science and mathematics mean scores per school and for the locale. The result is presented in Table 2.

Table 2: Students Learning Output

\begin{tabular}{lllllll}
\hline School & f & Chemistry & Biology & Physics & Maths & Average \\
\hline National & 2 & 8.11 & 7.96 & 7.11 & 8.06 & 7.17 \\
Extra county & 3 & 7.30 & 6.51 & 5.70 & 6.91 & 4.53 \\
County & 4 & 4.93 & 4.52 & 3.34 & 3.80 & 3.66 \\
Sub county & 6 & 3.63 & 3.41 & 2.82 & 3.54 & 2.91 \\
\hline
\end{tabular}

Siaya County average mean score 3.99

$N=361$

Source: Teachers' questionnaire and Students' Questionnaire

Table 2 shows that the national schools had the highest mean score in all the subjects at an average mean of 8.77, followed by Extra County schools at an average mean score of 6.61, then County schools at an average mean score of 4.14. The Sub County schools had the lowest mean scores in all the subjects at an average mean score of 3.35. Science and mathematics mean score for the locale was 4.75 which implies that the learning output in science and mathematics was low thus the performance was poor when compared to the total mean score of 12 points.

The subject mean scores were better in national and extra county category which are higher category of schools. The national schools performed almost three times better than the sub county schools in the four 
subjects. Subsequently, the performance gap narrowed with the county and extra county schools. The sub county schools attained about $30 \%$ of the scores of the national schools and nearly $50 \%$ of the scores of the extra county schools.

Chemistry had almost highest mean scores across all the category of schools; National (9.00), Extra County (7.30), County (4.93) and Sub County (3.63). The national school category performed better in mathematics (9.61), in the extra county category, chemistry yielded better result by a mean score of 7.3, in the county schools category chemistry had the highest mean score of 4.93 and finally among the sub county schools' chemistry performed better at a mean score of 3.63. Physics was poorly performed in all the schools.

Majority of the secondary schools in Siaya County were sub county schools at $78.3 \%$ in mixed day category and the performance portrayed in the sub county category was the least at a mean score of 3.35, which weighed down the overall county mean score. Students learning output was referred to as, the average mean score attained by learners in termly tests, set and marked by their teachers in their schools which was 4.75 for the locale. This result mimic Adrienne and Mbiti (2014) study which indicate that the most desirable Kenyan secondary schools are elite government schools that admit the best students from across the country and attain the best performance. Adrienne and Mbiti (2014) also indicate that the schools sterling reputation reflect the selection of students rather than their ability to generate value added test score gains.

\section{Influence of Per Student Expenditure on Learning Output}

Basing on per student expenditure and learning output in various schools in Siaya county, linear relationship was yielded from the tests of conformity via scatter plots. Regression analysis was then conducted and the results presented in Table 4.9 and Table 4.10.

Table 7: Statistical measurements of Per Student Expenditure on Learning Output

\begin{tabular}{lcccccc}
\hline Model & $\mathrm{R}$ & $\mathrm{R}^{2}$ & Adj. $\mathrm{R}^{2}$ & $\beta$ & Constant & Std. error \\
\hline 1 & $.787^{\mathrm{a}}$ & .619 & .616 & .787 & 3.47 & .052 \\
\hline $\mathbf{N}=\mathbf{3 7 6}$ & & & & & &
\end{tabular}

\section{Source: Principals' questionnaire, Teachers and Students' questionnaire}

The results in Table 7 shows that the Pearson's $\mathrm{R}=.787$ which implies that there is a strong positive linear relationship between per student expenditure and students learning output. The $\mathrm{R}^{2}$ value of .619 suggest that per student expenditure explained $61.9 \%$ of the variations in students learning output. The adjusted $\mathrm{R}^{2}$ also indicates that per student expenditure explained $61.6 \%$ of the variations in students learning output suggesting no addition input variables could improve the results.

The following regression equation was extracted from Table 4.9 to explain the magnitude and direction of per student expenditure on students' learning output in public secondary schools in Siaya County Kenya.

$\mathrm{LO}=3.47+.787 \mathrm{x}+\varepsilon(\mathrm{x})$

Where: LO represents the students learning output in the County; $x$ represents per student expenditure of the school category and $\varepsilon(\mathrm{x})$ is the chance of variation of the predictor.

The equation indicates a positive regression coefficient, a Beta weight of .787 which implies that one unit increase in per student expenditure caused .787 increase in students' scores in public secondary schools in Siaya County. The constant value suggests that the predicted value of students learning output is 3.47 if the value of students' expenditure is zero. However, the actual value of students learning output was established at 3.99 confirming that per student expenditure contributed to an increase in students' scores by .52. The standard error of estimate (E) was found to be $5.2 \%$, suggesting that there were other factors of the same magnitude that influenced the students' scores but not observed or taken into account by this study.

The significance of educational expenditure was linked to students learning output as affirmed by interviews conducted on the school principals. A principal from a county school reported that:
I must thank the government for the capitation grant to schools which has
enabled us run
almost all the school operations smoothly, if I may compare with the times when
there were no such grants. However, the grant is still not adequate to suffice the needs

of our school in regards to acquisition of learning materials, examination materials,

neither does the grant cater for the payment of services offered by teachers under BOM

employment terms. (Principal 6, January, 2021).

The convergence between the quantitative results and principals' views is on the significance of the expenditure on the learning resources which has enable acquisition of learning resources thus enhancing learning in schools, which is reflected in the improvement in learners' scores. This study finding is in agreement with Misra (2003) study in India, as cited by Anit (2017), the study found that improving public expenditure to education led to better attainment. However, this study finding contradicts UNESCO (2021) results which yielded mixed results about the causal relationship between school funding and performance pointing to variations in performance across schools within the country. However, UNESCO (2021) lauded the significance of government expenditure to finance school vote heads for quality education provisions. 
This study has established that there is a positive linear relationship between per student expenditure and students learning output though it is also important to note that performance cannot also be uniform across schools because of other factors such as students ability to grasp and internalise concepts, motivational levels of the learner and family background just to name a few which may confound to influence learner performance, what could be further considered is value addition through a comparative analysis with the entry behaviour of the learner to an education level. Expenditure to education is significant because it enables acquisition of the learning resources which facilitate learning and their effect are seen in the students learning output. World Bank (2017) study on education infrastructure and learning in the United Kingdom and

Romania indicate that there was $16 \%$ variation in students' academic performance due to environment and design element of the school infrastructure.

Table 8: Statistical measurements of Per Student Expenditure on Learning Output by School Categories

\begin{tabular}{|c|c|c|c|c|c|}
\hline Descriptive Statistics & $\begin{array}{l}\text { Sub } \\
\text { schools }\end{array}$ & county & County schools & $\begin{array}{l}\text { Extra county } \\
\text { schools }\end{array}$ & National schools \\
\hline $\mathrm{M}$ & 1.79 & & 2.10 & 1.90 & 1.50 \\
\hline SD & .53 & & .70 & .74 & .71 \\
\hline \multicolumn{6}{|l|}{ Regression Statistics } \\
\hline $\mathrm{R}$ & .27 & & .27 & .33 & 1.00 \\
\hline R- Squared $\left(\mathrm{R}^{2}\right)$ & .07 & & .07 & .11 & 1.00 \\
\hline Adjusted $R^{2}$ & .06 & & .06 & .07 & \\
\hline Beta $\beta$ & .27 & & .27 & .33 & $1 . \overline{00}$ \\
\hline $\begin{array}{l}\text { Standard Error of } \\
\text { Estimate }\end{array}$ & .16 & & .21 & .31 & .00 \\
\hline Constant & 3.77 & & 3.88 & 3.39 & .00 \\
\hline Learning Output & 2.91 & & 3.66 & 4.53 & 7.17 \\
\hline
\end{tabular}

$N=376$

Source: Principals' questionnaire, Teachers and Students' questionnaire.

Table 8 shows that the mean per student expenditure for were; $1.79(\mathrm{SD}=.53)$ for sub county schools, the county schools mean was $2.10(\mathrm{SD}=.70)$, extra county schools mean was $1.90(\mathrm{SD}=.74)$ and national schools mean was $1.50(\mathrm{SD}=.71)$. This suggests that averagely the sub county schools had the lowest per student expenditure of Kshs 112,500 per year compared to Kshs 150,007.80 in the county schools, Kshs 306,471 in the extra county schools and Kshs 453 249. 87 in the national schools' as indicated in Table 4.5. The National schools' had the highest per student expenditure per year.

The influence of per student expenditure on learning output was determined by the use of regression analysis which yielded regression coefficients that indicated the magnitude and direction of the relationship. The Pearson's $\mathrm{R}=.27$ for the sub- county schools', $\mathrm{R}=.27$ for the county schools and $\mathrm{R}=.33$ for the extra county schools denoted that there was a weak positive linear relationship between the per student expenditure and learners' scores in the school categories, while $\mathrm{R}=1.00$ for the national schools category indicated that there was a perfect positive linear relationship between the per student expenditure and learners scores.

The $\mathrm{R}^{2}$ explained the extent to which students learning output could change considering the value of per student expenditure in different category of schools. Table 4.10 indicate that the value of coefficient of determination $\left(\mathrm{R}^{2}\right)$ was higher in national schools category at $\mathrm{R}^{2}=1.00$ followed by Extra county schools at $\mathrm{R}^{2}$ $=.11$ then County schools at $\mathrm{R}^{2}=.07$ and lastly Sub county schools also recorded $\mathrm{R}^{2}=.07$. The $\mathrm{R}$ - Squared $\left(\mathrm{R}^{2}\right)$ values yielded suggest that, the per student expenditure explained $100 \%, 11 \%, 7 \%$ and $7 \%$ the variations in students learning output in the National, Extra County, County and Sub County schools respectively. The low values of the Adjusted $R^{2}$ of $.06, .06$ and .07 for the sub county, county and extra county schools respectively, portray the factual extent of the contribution of the per student expenditure in explaining the variations in the learners scores in the school categories suggesting that there are no additional input variables to add value to the model.

The magnitude and direction of the influence of per student expenditure on learners' scores is explained using the following regression equations:

$\mathrm{LO}_{\mathrm{N}}=.00+1.00 \mathrm{X}+\varepsilon(\mathrm{x})$

$\mathrm{LO}_{\mathrm{EC}}=3.39+.33 \mathrm{x}+\varepsilon(\mathrm{x})$

$\mathrm{LO}_{\mathrm{C}}=3.88+.27 \mathrm{x}+\varepsilon(\mathrm{x})$

$\mathrm{LO}_{\mathrm{SC}}=3.77+.27 \mathrm{X}+\varepsilon(\mathrm{x})$

Where: $\mathrm{LO}_{\mathrm{N}}, \mathrm{LO}_{\mathrm{EC}}, \mathrm{LO}_{\mathrm{C}}$ and $\mathrm{LO}_{\mathrm{SC}}$; represent the students learning output in the National, Extra County, County and Extra County School categories in the County respectively; $x$ represents per student expenditure of the school category and $\varepsilon(\mathrm{x})$ is the chance of variation of the predictors.

The Beta weights $(\beta)$ predicted that one-unit increase in per student expenditure is expected to cause 
$1.00, .33,27$ and .27 increase in learners' scores in the National, Extra County, County and Sub County schools respectively. The constant values of 3.77, 3.88, 3.39 and .00 for Sub County, County, Extra County and National schools suggest the predicted value of the students' scores in the schools if the value of per student expenditure is zero. This compared against the actual learning output values of 2.91, 3.66, 4.53 and 7.17 for Sub County, County, Extra County and National schools respectively indicated that per student expenditure increased the students' scores by .22, 1.14 and 7.17 in the County Schools, Extra County and National respectively except for the sub county schools where the students' scores reduced by .86. The standard error of estimates (E) was found to be .16 .21 and .31 for the sub county, county schools and Extra County respectively which suggest that there were other factors of the same magnitude that influenced the students learning output by the same magnitude but were not accounted for in the model. National schools had .00 error implying that no other non-observable factors confounded to affect the outcome of the study.

This study therefore established that per student expenditure influenced learners' scores in varying magnitudes across the school categories, though the influence was higher in the national schools and lowest in the Sub County and County schools. This is factual in regards to the need variations in the school categories and other unobserved factors like students' abilities, parent's educational background, which could influence students learning output.

This study also embraced the qualitative approach whereby school principals, science and mathematics teachers and students were interviewed so that they could supply their views on the how the various expenditure areas in their schools influenced learning in their schools and consequently students learning output. From the principals' interview, a question on the view about the government spending in school with regard to the quality of the provisions for learning which such expenditure relate to, generated responses as presented in the following verbatim.

A principal from an extra county school reported that:

The school has to fall back to the parents to provide what is required for quality teaching and learning, the vote head from which the school draws funds for learning materials can not sufficiently provide for the amount of chemicals we need to run practical classes in the laboratories therefore, students pay for academic support programs and additional funds to be used to purchase the chemicals for practical and it is from these funds that we also pay salaries for our teachers who are employed by the BOM, and therefore each student pay Kshs 7000 to support such arrangements (Principal 5, January, 2021).

A further confirmation was yielded by another principal from a county school who said that:

The capitation grant is not adequate, leaving the school with no choice but to run back to the parents to bridge the gap. The students are therefore required to buy and bring to school some books, their own items such as logarithm tables, mathematical set, pens and ream papers for examination because in this instance, what the government provides can only last one exam such that mock alone can clear the government provision for examination materials for a term, while frequent formative testing is required for quality outcome in the summative examination (Principal 5, January, 2021).

A student from a County school expressively reported that:

Students are even sent home for school uniform, lunch levy and ream papers which are inclusive in the fee and are deducted first when fee payment is made. Failure to pay, students miss the lessons as they are sent home thus such students may fail in exams if they themselves fail to seek assistance from the teachers or fellow students to help them understand the content taught while they were absent (Student 22, January, 2021).

A student from a sub county school said that;

The school laboratory has been under construction for a long time, and is not complete, thus we do our practical lessons mostly in the classrooms which have no laboratory requirements and not enough space hence not effective environment for practical leading to inaccurate results. The inadequate resources in our school also brings laziness to students who might not do the practical and since during examination you have to do the practical alone, the students fail because they do not have the skills required to perform the practical (Student 25 January, 2021).

The quantitative findings were in convergence with the qualitative findings as views were being triangulated, that per student expenditure was an important predictor of students learning output in public secondary schools in Siaya County. The convergence was around the fact that expenditure determined the extent of learning in regards to the adequacy or inadequacy of the learning requirements. In cases where learning resources were inadequate due to less capitation and lack of payment by the students, the students' scores were affected negatively.

Kenya education policies define the standard requirements for quality learning which are then cascaded 
downwards to the school level for implementation purposes by the schools Board of Management (Republic of Kenya, 2018). The general view of the principals, teachers and students established that the expenditure areas should be catered for adequately for effective and quality learning to take place. There is concurrence that there are requirements that must be serviced by the learners' failure to which the students are sent home to pay, while such students' miss on the learning lessons back at school and this negatively influenced learners' scores.

These findings concur with a study by World Bank (2017) which indicated a 16\% variation in students' scores in the United Kingdom and Romania due to the environmental and design elements of the schools, pointing to the fact that in Romania, students from low income and rural families attended poorly equipped schools. Schools thus need adequate financing and mechanisms to ensure equity and efficiency coupled with accountability and transparency for improved educational outcomes (UNESCO, 2021).

Generally, the charges falling on the households and inadequate government capitation were mainly to blame for the inadequate infrastructural and instructional needs of the schools thus the low learning output. Majority of the students indicated settling the school requirement either when the term is almost coming to an end or never pay for them until such a time they would be clearing from school after finishing form four, even though they could have missed such services during the time in which they were offered.

The current study findings are in agreement with Changhui (2019) who found that $10 \%$ increase in school expenditure caused 0.56 percentile point improvement in test scores. Also, this study findings are in agreement with Wanga (2014) and Odhiambo (2018) studies conducted in Siaya County which found that schools charged extra levies on students' accounts. These included; development fees and academic support programs (remedial levy, BOM teachers' salary), making learning not to be continuous for many students whose parents could not afford to pay for such charges. These findings further concur with UNESCO (2017b) study which found that families in Africa carry the biggest burden in educating their children as governments spend less of the country's GDP on education and this hinders educational outcomes. Moreover, Chris, et al. (2019) found that high performing schools tend to be relatively well equipped. This was corroborated by this study findings whereby; the National schools had the highest public expenditure which was reflected in the value of the buildings and other infrastructural facilities. The National schools also had the highest learning output (mean scores). Learning output was seen to increase with every higher categorization of schools. Therefore, national schools registered better learning output, followed by extra county schools, then county schools while the sub county schools which had the lowest per student expenditure attained the lowest learning output.

These findings are valid because students paid for academic support programs through parents' association (PA) accounts to facilitate salary payment for teachers employed under Board of Management (BOM). The students equally provided for their own writing materials such as; pens, books and other learning utilities. Students further purchased their own uniforms which comprised of; skirts, blouses, trousers, shirts, sweaters, socks, shoes tie and game skits fully on their account in addition to paying development fees.

These study findings also concur with a study by Steel and Smith (2017) and UNESCO (2015b) which indicated that a rise in government expenditure to education leads to a reduction in the education inequalities and thus improved equity in access to education and educational outcomes.

Nevertheless, the current study findings contradict Hanushek (2008) study in the United States which found that increasing school resources had no direct influence on students' achievements. This study established that more resources to education meant better quality of learning as was reflected in the students learning output.

\section{CONCLUSION AND RECOMMENDATIONS}

\section{Conclusion}

The influence of per student expenditure on learning output was determined and the results show that, the per student expenditure have a great influence on students learning output. There was a strong positive linear relationship between per student expenditure and learning output. Per student expenditure explained more than half $(61.9 \%)$ of the variations in students' learning output. The various categories of schools; Sub County, County and the Extra County schools registered weak positive linear relationships between per student expenditure and learning output. However, the national schools had a perfect positive linear relationship between per student expenditure and learning output. The per student expenditure made less than quarter of the contributions in the students' learning output among the sub county, county schools, and extra county schools and $100 \%$ contribution to the students learning output in the national schools.

The qualitative results where the participant's views were sought to explain the influence of the expenditures on learning revealed that all the expenditure areas were significant in the achievement of quality learning though parents could not adequately afford their part of expenditure requirements either in time or completely which affected the quality of learning. Therefore, it was established that student expenditure was an essential quality variable and influenced learning output, though private expenditure was still not adequately serviced thus hindered learning mostly in the sub county and the county schools.

It is concluded that the per student expenditure is an essential determinant of students learning output, has a 
great influence on learning output and that the more the resources the better the learners scores. Private expenditure averagely still outweigh the amount of government capitation grant per child; parents still incur huge private costs in education of which is seen as a hindrance to students learning output because some necessary learning resources may not be acquired in time for effective learning as parents either pay for them late into the term or at the end of year hence such resources are not utilised in the learning process when they are needed, compromising content delivery and consequently reducing learning output. Therefore, the higher the resources in terms of per student expenditure the better the learning environment and learning output.

In addition, the system of education financing is mainly horizontal providing equal amounts for different learner needs posing an equity gap as vertical equity is ignored. This still was a threat to the quality of education received by the individual learners in several schools within the locale, taking into account the varied socio economic characteristics in the region, of which majority of the households could not settle the school requirements in time.

The sub county schools were the cheapest in every expenditure area though they were in the same vein gravely affected by lack of the most vital educational infrastructure such as inappropriately constructed laboratories, few laboratories, inadequate laboratory equipment and insufficient chemicals and less staff. The national schools drew the largest capitation grant due to the high enrolment in the schools compared to the Extra County, County and Sub County schools. Though the inadequacy of the learning requirements also dotted all the schools, the sub county and county schools were much affected and this caused reduced learning output. The SDG4 aiming to attain inclusive and equitable quality education and lifelong learning opportunities for all, by the year 2030, could be a mirage with the dwindling resources at especially the county and sub county schools compromising the quality of learning in the schools. Although the study found evidence of improved learning output with higher per student expenditure, the study was not able to establish how much the students' abilities could have contributed to leaners' scores, given the fact that learners are admitted to various categories of schools considering their ability.

\section{Recommendations}

1. Due to the heavy private expenditure posing a burden to the parents leading to late payment thus compromising the quality of learning in schools, the government should allocate more subsidy by catering for salaries to the teachers employed under Board of Management, subsidize on school uniform and meals to learners within areas which portray direly low socio economic characteristics. This will help reduce the household burden on such expenditure and improve on vertical equity.

2. The ministry of education to increase grant for development expenditure which also had a negative influence on learning as some schools ended up charging students up to Ksh. 10,000 while explaining that they needed to put up more classrooms to accommodate increased enrolment.

\section{Acknowledgement}

This work would not have been completed without God's mercies, Glory to Him. Sincere and profound gratitude to my supervisors; Prof. John, Aluko Orodho and Dr. Thaddaeus Ogola Rugar, both of the department of Educational Management, Policy and Curriculum Studies, School of Education, Kenyatta University, for their tireless efforts which enabled the completion of this study. Special thanks to the schools where the research was undertaken. To my family all who helped in one way or the other, may the Almighty God bless you abundantly!

\section{References}

Anit, N. M. (2007). Public expenditure on education: a review of selected issues and evidence. Retrieved from www.researchgate.net.

Creswell, J. W. (2014). Research design: qualitative, quantitative, and mixed methods approaches. $4^{\text {th }}$ ed. Thousand Oaks, California: SAGE Publications.

Creswell, J. W. \& Plano Clark, V., L. (2011). Designing and conducting mixed methods research. Thousand Oaks, C. A: SAGE Publications.

Getange, N., Onkeo, M. J., \& Orodho, J. (2014). Alternative sources of funding For Free Day Secondary Education (FDSE) in public schools in Kisii Central District, Kisii County, Kenya. Journal of Dental and Medical Sciences, 13(4), 14-23.

Hanushek, E. A. (2008). Education Production Functions. Basingstoke: Palgrave Macmillan.

KIPPRA. (2019). Tightening compliance of the Basic Education Act to ensure complete and seamless transition across all levels of schooling. Policy brief no. 54 of 2018 - 2019. Retrived from http://repository.kippra.or.ke

KIPPRA. (2017). The determinants of technical efficiency in secondary schools in Kenya. Discussion paper No. 199 OF 2017. Retrived from http://repository.kippra.or.ke

Kothari, C., R. (2004). Research methodology: Methods and techniques. New Delhi: New Age International (P) 
Ltd.

Lucas, A. M. \& Mbiti, I. M. (2014). Effects of school quality on students' achievement: discontinuity evidence from Kenya. American Economic Journal: Applied Economics, 6(3), 234-263.

Mugiraneza, J. P. (2018). Hidden costs and their impact on students' participation in basic education, Rwanda. Retrieved from https://ir-library.ku.ac.ke.

Ngalu, M., M. \& Bommet, J., E. (2014). The role of Constituency Development Fund provision of secondary education in Kenya. IJSTR.

OECD, (2014a). Education at a glance. Paris: OECD Publishing

OECD, (2014b). How much time do students spend in classroom? Paris: OECD Publishing.

OECD, (2018). How much is spent per student on educational institutions. OECD Publishing. Paris.

Orodho, J.A. (2012). Elements of education and social science research methods. Maseno; Kanezja Publishers.

Orodho, J., A. (2014). Financing basic education: What are the equity and quality implications of Free Primary Education (FPE) and Free Day Secondary Education (FDSE) Policies in Kenya? International Journal of Development Research, 4(3), 477-487.

Orodho, J. A. (2017). Techniques of writing research proposals and reports in education and social sciences: An illustrative approach to scholarly excellence. Nairobi: Kanezja Publishers \&Enterprises.

Orodho, J., A., Ampofo, Y. S., Bizimana, B. \& Ndayambaje, I. (2016). Quantitative data management: A. step by step guide to data analysis using Statistical Package for Social Sciences. Nairobi: Kanezja Publishers \& Enterprises.

Orodho, J., A., Nzabalirwa, W., Odundo, P., Waweru, P., N. \& Ndayambaje, I.

(2016). Quantitative and qualitative research methods: A step by step guide to scholarly excellence. Nairobi: Kanezja Publishers \&Enterprises.

Republic of Kenya. (2018). Operation manual for utilization of learner capitation grant and other school funds. Retrieved from http://www.education.go.ke.

Republic of Kenya. (2019). Basic Educational Statistics. Nairobi: Government Printer.

Republic of Kenya. (2020). Secondary schools 2020 fees structure for national schools, extra county, county, sub county and day schools. Retrieved from https://teacher .co.ke.

Solow, R., M. (1966). Some recent development in the theory of production. Massachusetts Institute of Technology: MIT Press.

Thuo, M. (2020). Supporting deserving students through CDF funded scholarships. Retrieved from www.capitalnews .co.ke.

Ugwalashi, S., C. (2012). Parents Teachers Association (PTA) roles and funding of private school administration in Nigeria. AJMSE, 1(2), 2186-8441.

UNESCO. (2012). From access to equality: Empowering girls and women through literacy and secondary education. France: UNESCO.

UNESCO. (2014). The Kenya Vision 2030. RTRIVED from https://www.unesco.org.

UNESCO. (2015a). Education 2030 Framework. New York.

UNESCO. (2015b). EFA Global Monitoring Report 2015; Education For All 2000- 2015, Achievements And Challenges. Global education monitoring report. Paris: UNESCO.

UNESCO. (2015c). Zambia: Education for All 2015 National Review. Zambia: UNESCO

UNESCO. (2015d). Improving learning: Instructional time and classroom Management. UNESCO: IIEP.

UNESCO (2016a). School Resources and Learning Environment in Africa: Factors Affecting Quality Education. UNESCO Organization.

UNESCO. (2016b). Leave no one behind: How far on the way to universal primary and secondary education?

UNESCO. (2016c). Global Monitoring Report: Every Child Should Have a Text Book.

UNESCO. (2017a). Education centres, Annual expenditure per student.

UNESCO (2017b). Sustainable Development Goal.

UNESCO (2018a). Global Education Monitoring Report.

UNESCO (2018b). Advocacy for quality Education for All in Africa.

UNESCO. (2018c). Lower secondary school completion rates. UNESCO Institute of Statistic.

UNESCO (2019b). Gender inequality in STEM Education. www.unesco.org.

UNESCO (2019c). Resources for teaching and learning of Mathematics and Science in School. UNESCO Organization.

UNESCO. (2019d). Sustainable Development Goal Four Resources for Educators. UIS.

UNESCO (2021). Financing education and addressing corruption: Brief 5. UNESCO Organization

UNICEF. (2014). Basic Education Statistical Booklet. Unicef.Org. C

UNICEF. (2015). Annual Results Report. Unicef.Org.

UNICEF. (2017). Knowledge for Children in Africa. Unicef.Org.

Wambugu, J. \& Makoena, S. (2013). Education financing in Kenya: parents' perceptions about implementation 
of the cost - sharing policy in secondary school education. Mediterranean Journal of social sciences, doi:10.5901/mjss.2013.v4n13p441.

World Bank (2017). Why Education Infrastructure Matter for Learning. Washington D.C.: World Bank.

World Bank (2018). Learning to Realize Educations Promise. Washington D.C.: World Bank. 